\title{
Blížíme se evropské kulturní identitě?
}

\author{
George Schöpflin
}

Problém evropské identity neplyne z toho, že neexistuje, nýbrž z toho, že můžeme velice obecně definovat evropské identity dvě, politickou a kulturní, které nejsou v mnoha ohledech v souladu. Proces evropské integrace ve stávajícím pojetí proto dosahuje svých mezí, a dokud nebude změněn současný stav, nenastane výrazná náprava.

Politická Evropa je výsledkem pěti desetiletí evropské integrace a stává se paradoxně stále méně politickou v pravém smyslu slova, nebot' je nahrazována politikou chápanou jako management. Politika v tomto pojetí je strukturována zřejmým závazkem vůči konsenzualitě, procesu, administrativním řešením a je určována elitami. Politická rozhodnutí jsou činěna převážně členskými státy EU, zejména velkými; za těchto okolností je diskuse o Evropě omezená. Politika jako soutěž idejí a střet zájmů je provozována v nejlepším případě za zavřenými dveřmi, veřejnosti náleží pouze její malá část, a proto existuje jen malá naděje na vytvoření celoevropského veřejného mínění. Mnohem obtížnější je ovšem definovat kulturní Evropu, nebot' ta je ve skutečnosti velice diskutabilní. Pokud má kulturní Evropa nějakou náplň, pak je jí kulturní diverzita - rozrůzněnost s určitou sadou sdílených implicitních předpokladů a způsobů, jak vyjednávat o rozdílech. Je výsledkem dlouhodobě sdílených historických zkušeností a - možná především - osobitého způsobu definování modernity, který poprvé vznikl na západním okraji Evropy a posléze inicioval další na různých místech kontinentu. Všechny tyto formy modernity jsou si obecně podobné, výrazně se liší v detailech. Interkulturní komunikace je tedy možná, ale jen zř́ídkakdy jednoduchá.

Jedním z klíčových aspektů evropské kulturní identity je obtížný a rozporuplný vztah mezi kulturami a politickou mocí. Konceptem, který tyto elementy kombinuje v nejvíce viditelné podobě, je národní stát. Je to vysoce komplexní entita, mnohem komplexnější, než prohlašují její protagonisté i očerňovatelé, v jejímž jádru stojí řada tvrzení nebo - možná ideálů. Národní stát byl konstruován k zabezpečení kulturní reprodukce, k poskytování koherence a bezpečnosti a k zajištění př́istupu všech členů kulturní komunity k politické moci. Pro modernitu je ústřední konsenzuální vláda, demokracie, určitý stupeň kontroly v rukou jednotlivých občanů nad jejich vládci. Dvacáté století ukázalo, že výkon politické moci bez souhla-

Sociální studia. Fakulta sociálních studií Masarykovy univerzity v Brně, 1/2004. S. 121-128. ISSN 1212-265X. 
su je možný, ale nutně končí zhoubně (komunismus, fašismus). Obtíže pak plynou z toho, že souhlas - podobně jako u celé řady jiných jevů - je kulturně kódovaný, a to, co je v jednom státě považováno za konsenzuální vládu, není nutně chápáno stejným způsobem v jiné zemi. Např́iklad anglosaský pragmatismus v sobě zahrnuje nesrovnalosti neslučitelné s karteziánským myšlením.

V této souvislosti přispěly události posledních padesáti let k velmi zvláštnímu chápání politiky v Evropě, a to k tvrzení, že kultura a politika jsou oddělitelné a politika spočívá v managementu a správném nastavení technologie vládnutí. Mohlo by se zdát, že tento stále populárnější názor mohl být vyvozen z následků druhé světové války, ze způsobu, který válku soustavně vykládá jako excesy v chování národních států - způsobu redukcionistického v důsledku nevyslovené domněnky, že vláda zbavená kultury je nejen možná, ale prrímo žádoucí. Také úspěch evropského projektu, pád komunismu a postulát „konce“ dějin přispěly k depolitizaci politiky. Ukázkovým př́kladem je třetí cesta prosazovaná stranou New Labour.

Ve skutečnosti je jedním z velkých úspěchů Evropy chápané jako kultura její schopnost kombinovat výjimečný stupeň kulturní diverzity s obdobně diverzifikovanými projevy politické moci. Žádná jiná část světa nezahrnuje tolik kulturních komunit, které jsou zároveň autonomními politickými komunitami. Otázkou ovšem stále zůstává, kde by mezi nimi měla ležet hranice. Př́lišná kulturní autonomie způsobuje nejen izolaci, ale může se rozvinout v ohrožení sousedů, pokud kulturní autonomie v domnělé obraně vlastní kultury užívá praktik, které porušují kontingentní evropské normy (napřr. normativita v oblasti lidských práv). Pozitivním aspektem tohoto stavu je, na druhou stranu, možnost zvýšit potenciál kulturní kreativity, protože různé kultury - $\mathrm{v}$ tomto př́padě vysoké kultury - experimentují s různými řešeními a umožňují vzájemné obohacování zabraňující stagnaci.

A dále - zatímco Evropa byla konstruována převážně technokratickými a manažerskými metodami, národní státy se mezi sebou naučily žít prostřednictvím různě ustanovených a realizovaných mechanismů zajišt’ujících, že se kulturní komunity, jež pocitují ohrožení vlastní kulturní reprodukce, nebudou chovat destruktivně. Základem těchto mechanismů jsou vzájemná uznání a sebeomezení na kulturní úrovni, řada procesů zahrnujících jazyk, symboly, rituály, pamět' a partikulární zvýznamnění vytvářené a reprodukované jednotlivými kulturami. Ovšem na evropské úrovni byla tato forma kulturní konstrukce z velké části - ačkoliv ne úplně - ignorována. Manažerská politika je pochopitelně mnohem jednodušší.

Řada komentářů soudí, že Evropě nyní schází vize, procesy spojené s Evropou přitahují velice omezenou masovou identifikaci a že politika evropské integrace postrádá hlubší legitimitu. To vše vytváŕí pocit, že „technologické Evropě“ neodpovídá „Evropa politická“, v níž politika zahrnuje základní kulturní normy definující politickou moc. Evropská unie do značné míry splňuje cíle, pro které byla založena, zůstává organizací, jež má moc kontrolovat některé oblasti ekonomického a komerčního života prostřednictvím celé řady komplexních administrativních nástrojů a navzdory různým politickým nadstavbám zůstává manažerská.

Připomeňme, že celkově je Evropská unie velmi efektivní v tom, k čemu byla určena, a vskutku dosáhla základního cíle - zajištění míru v Evropě, jejž má Unie a její členské státy pod kontrolou. Mezery nacházíme v druhu politické aktivity, která vyžaduje mnohem větší prŕmou identifikaci, což opět nastoluje otázku společné a artikulované kultury, včetně otázky zvýznamnění. Ve zkratce - vize vyžaduje společnou kulturu na úrovni, na které má mít ode- 
zvu. Po roce 1945 existovala taková vize, a to vize o vytvoření Evropy bez válek, přesněji o ukončení franko-německého antagonismu. Studená válka se stala dodatečným pomocným faktorem. Dnes taková vize neexistuje.

Existují vážné důvody, kvůli kterým se Evropa a elity, jež definují kulturní normy, neúčastní těchto procesů. Přestože vzpomínky na druhou světovou válku už vybledly, ještě zcela nevymizely - obě světové války naopak zanechaly tak hluboké stopy ve vědomí západní Evropy, že existuje jasný a nevyslovený imperativ „nikdy více“. A jelikož je za primární př́íčinu války opakovaně označován nacionalismus, začínající podle definic většinou kulturním nacionalismem, odpor k propojení kultury a politiky je hluboký a pro své internalizování obtížně rozpletitelný.

Problematiku evropské kultury komplikují dvě základní otázky. První - kde leží hranice Evropy, druhá - kdo je a kdo není Evropan. Obě představují velice obtížné problémy, natolik obtížné, že jen málo lidí je připraveno stanout jim tváŕí v tvář, nebot' existuje třetí faktor - nárok na univerzalismus. Tento faktor v podstatě říká, že každý, kdo žije v Evropě a přijme podmínky Evropy chápané jako politický management, může být Evropanem, předpokládá tedy, že imigranti přicházejí do Evropy kulturně „nazi““ a musí se jen minimálně přizpůsobit, aby se stali užitečnými občany. Problémy, které se v procesu integrace vyskytnou, jsou odsunuty jako vina většiny (tj. rasismus). Tento pohled nachází ohlas, avšak je chybný, protože v zásadě zastírá kulturu Evropy i kulturu imigranti̊.

Daná problematika má vliv na další dva faktory. Pokud je Evropa chápána pouze jako záležitost politické technologie a dodržování řady politických a právních norem, pak se Evropanem může stát každý a Evropa teoreticky nemusí mít žádné hranice. To jednoznačně rozptýlí pochybnosti o přináležitosti Ruska a Turecka k Evropě. Teoreticky (dle této definice) tedy neexistuje žádný důvod, aby se např́íklad Pákistán, jestliže se podřídí acquis a normativitě lidských práv, nemohl jednoho dne dožadovat přijetí do Evropské unie. Pokud však vezmeme v úvahu pochyby týkající se dokonce i přijetí Turecka, je obtížné popřít, že existuje jakési chápání společné evropské kultury.

Problémem ovšem je, čím tato kultura vlastně je, a také jak ji definovat způsobem, který by vyvolal odezvu, ale - především - zda může být dostatečně zhuštěna, aby na evropské úrovni umožnila legitimizaci prostřednictvím identifikace. V tomto ohledu jsou pochybnosti ještě větší než v minulosti. Existují nejen zcela reálné obtíže s integrací neevropských imigrantů do něčeho, co připomíná zhuštěnou evropskou kulturu (nemluvě o silném odporu, jejž by zhuštění vyvolalo u těch, kteří si uvědomují, že hustější soubor kulturních norem by učinil integraci Neevropanů mnohem obtížnější), ovšem svou roli by sehrál také méně zřetelný odpor národního státu.

Evropský národní stát je v mnoha směrech pozoruhodným nástrojem $\mathrm{k}$ řešení řady politických a kulturních problémů. Uspěl ve vytvoření systémů, do nichž byl kulturně zakódován souhlas s vládnutím bez jeho zjevného kódování. Standardně se tvrdí, že souhlas s vládnutím je v konečném důsledku zakotven v občanské smlouvě. Ve skutečnosti existuje silné kulturní kódování občanství a občanských práv - letmý pohled na charakter francouzských a nizozemských konceptů občanství odhaluje značné rozdíly kulturního charakteru, ale toto kulturní kódování bylo zastíněno faktory, které už byly naznačeny a které zahrnují univerzalismus, asociaci národa s válkou a diverzitu. 
Zásadní charakteristikou souhlasu s vládnutím je, že zahrnuje nevyslovené kulturní kódování, na které spoléhá jako na pokračující proces v neposlední řadě kvưli tomu, že moderní stát neustále rozšiřuje vlastní racionalizující aktivitu a potřebuje tichý souhlas ovládaných k dosažení efektivity. Občanská smlouva funguje jako diskurzivní strategie, ale spoléhá na implicitní hodnoty kulturních norem, jež zahrnují a vylučují. Reciproční vztah mezi vládnoucími a ovládanými, na kterém je demokracie založena, musí spoléhat také na vysokou úroveň důvěry. Tato důvěra existuje paralelně s pocitem solidarity. Solidarita se tvoří a reprodukuje, jestliže si lidé osvojí diskurzy, které v rámci komunity umožňují vzájemné uznání. Bez tohoto jednoznačně kulturního základu je obtížné zachovat demokracii.

Toto tvrzení objasňuje, proč se kulturní Evropa jeví jako nezbytná součást prohloubení evropského projektu. Stejně tak objasňuje, proč je pohyb daným směrem tak obtížný. Nejenže zhuštěná evropská kultura je velmi diskutabilní záležitostí a křižovala by existující závazky $\mathrm{k}$ diverzitě, ale je obtížné představit si, že by se národní stát bez donucení vzdal toho, čeho v této oblasti dosáhl. Nejpravděpodobnějším takovým nátlakem je globalizace, ovšem pouze s obtížemi bychom mohli tvrdit, že globalizace momentálně představuje natolik silné ohrožení, aby nutila národní stát ponořit se do širší evropské identity.

\section{Střední Evropa a Evropská unie}

Rozšíření Evropské unie je téměř završeno, postkomunistickým zemím střední Evropy bylo přislíbeno plné členství od 1. května 2004. Přizpůsobování se požadavkům EU transformovalo v postkomunistickém světě celou řadu aktivit, např́iklad v oblasti zdravotnictví, bezpečnosti, ochrany životního prostředí, regulace finančních služeb, a zvýšilo také kapacitu státní administrativy a soudnictví. Rozšíření je již nyní ekonomickou, politickou, a do značné míry i právní realitou. Stále více se stává také kulturní realitou (kulturní v nejširším smyslu slova), ačkoliv v této oblasti existují ve střední i v západní Evropě nejzávažnější problémy.

Jak se zdá - stručně řečeno - do značné míry se jedná o to, že diskurzy potřebné k tomu, aby společnosti v kandidátských zemích cítily, že jim náleží členství v EU, zatím vůbec nebyly vytvořeny nebo jsou vytvořeny jen částečně. Prozatím projevuje veřejné mínění omezené pochopení toho, co členství v EU zahrnuje. V několika kandidátských zemích vskutku klesá s blížícím se připojením nadšení, což naznačuje, že politicko-manažerská Evropa je sama o sobě problémem pravděpodobně kvůli tomu, že s nárůstem informovanosti o EU dochází ke střetům s existujícími domněnkami o politických normách.

Technické elity ze střední Evropy, které byly přímo zapojeny do vyjednávání s Bruselem, velmi rychle a úspěšně vstřebaly znalosti o EU - především o metajazyce, formálních a neformálních způsobech vyjednávání, rozsahu závazků a povinností, které EU ukládá. Uzavření kapitol je pro ně důležitou lekcí - skutečným znovunavázáním spojení s Evropou a socializací se způsoby, jakými je EU provozována.

Tyto formy vědění ovšem nebyly předány názorotvorným elitám v různých kandidátských zemích. Existuje značný odpor vůči předání, nebot’ toto předání vyžaduje rezignaci na formy vědění vytvořené $v$ době postkomunismu, které jsou zásadní pro udržení vysokého statusu těchto elit. Nejenom že přetrvává to, co Zygmunt Bauman před desetiletím charakterizoval jako liminální stav postkomunismu, v němž součásti starého a nového koexistují a různé diskurzy ve skutečnosti nefungují v interakci, ${ }^{1}$ ale tento stav přetrvává kvůli tomu, že 
názorotvorné elity se ve veřejné sféře snaží zabránit novým myšlenkám a novým vstupům, jelikož každá změna znehodnocuje stávající vědění. Elity tak činí alespoň částečně tím, že aktivně odolávají inovaci ve veřejné sféře prostřednictvím konstrukce nových diskurzivních arén, které by zvýznamnily vlastnictvím diskurzů EU. Aby se diskurzy integrovaly, musely by postkomunistické elity přijmout mnohem silnější reciproční vztah mezi sebou a společností a musely by se vzdát velké části své legislativní role, tradičně legitimizované tím, že tyto skupiny jsou označovány jako „svědomí národa“.

Společnosti tedy do velké míry neznají všechny informace o členství v EU. Mohou být obeznámeny s dílčími aspekty, například s aktivitami složek EU, které zavádějí mnohem př́ísnější podmínky pro ekonomické aktivity - avšak tvrzení, že tyto změny mohou mít pozitivní výsledky, většinou přehlížejí. Ve skutečnosti je potřeba exkluzivní suverenity stále živá, přetrvává přístup „my sami“, prř́stup, podle kterého je jednoduše možné spravovat zemi do velké míry odtrženě od zbytku světa. Koncept, dle něhož se členské státy EU vzájemně nepovažují za cizí jednotky, ale naopak za partnery, je zatím velice vzdálen možnosti přijetí na elitní a populární úrovni. Jako ilustrace může posloužit neochota České republiky souhlasit s tím, že provozování jaderné elektrárny v Temelíně není její vnitřní záležitostí, ale ovlivňuje také Rakousko a Německo. V současné době převažují celoevropské záležitosti a v rámci EU má koncept „vnitřní záležitosti“" stále menší význam.

To vše má určité důsledky - vstup do EU bude pro střední Evropu s velkou pravděpodobností kulturním šokem. ${ }^{2} \mathrm{~V}$ některých př́padech bude vyjádřen ve formě nativismu, xenofobie a odmítnutí nového - tedy ve formě toho, na co rádi s užaslou fascinací pohlížíme jako na novou radikální pravici. Zmínka o tomto jevu vyvolává v mysli jména Lepper a Csurka³ Záležitosti se dále vyhrocují v důsledku globalizace, proti jejímž účinkům EU sice poskytuje určitou ochranu, ale činí tak za cenu pohlcení lokálních hodnot, vzdání se lokálních způsobů a forem vědění.

Odpůrci Unie našli další povzbuzení pro vlastní přesvědčení ve způsobu, jaký EU zvolila pro vyjednávání o vstupu středoevropských zemí. Jednoduše řečeno, vyjednávání bylo poznamenáno nedostatkem vyváženosti a pochopení pro obavy kandidátských zemí. EU v podstatě vnutila střední Evropě acquis communautaire, projednávaly se detaily, ne principy. K legitimizaci byla použita metafora „vstupu do klubu“; metafora je ovšem chybná. Byla by přesvědčivá pouze v prŕípadě, kdyby existovaly i jiné kluby, do kterých by mohla střední Evropa vstoupit, kdyby existoval výběr mezi kluby. Takový výběr však neexistuje.

EU nevzala v úvahu řadu faktorů, které jsou pro střední Evropu specifické a které mohou mít nezamýšlené důsledky, ovlivňující fungování rozšířené EU. Je obecná pravda, že bez normativní diskuse nejsou myšlenky, pravidla a koncepty internalizovány, nýbrž vnuceny. Vnucení pravidel s sebou nese vyhovění, ne však konsenzus. Pravidla, jež jsou vnucena, nebudou implementována ve stejném duchu, v jakém byla vytvořena, ale podvracena nebo ignorována, kdykoliv to bude možné. Toto je jedno z ponaučení dob komunistické nadvlády. Západ si vytvořil ke střední Evropě určité paternalistické přístupy, stručně formulovatelné jako „Západ ví nejlépe“ - mělo být zanecháno lokálních diskurzů, postupů a hodnot, nebot’ byly chápány jako negativní. Tomu odpovídá nevyslovené přesvědčení, podle kterého střední Evropa nemůže nijak užitečně přispět ke konstrukci Evropy. Nejvýraznějším př́kladem je radikální způsob, jakým bylo východní Německo asimilováno do Německa západního. 
Roli protějšků paternalismu plní ve střední Evropě již vytvořené historické modely soužití v jednostranném vztahu, který může být stručně popsán jako následek interakce evropských velmocí a malých států. ${ }^{4}$ Tyto modely byly hluboce kulturně zakódovány a přetrvávají. Neexistuje proto silné uvědomování si vlivu, vlastně ani nemůže existovat, nebot' volby jsou omezené a na preference se pravidelně nedbá. Z toho pramení známé diskurzy „náhodného vývoje“, „překážek“, „co to s námi chtějí udělat“. Nedostatek alternativ k EU vytváří pocit nevyhnutelnosti a fatalismu, které rozkládají středoevropské vnímání sebe sama.

Nemusíme jít tak daleko jako József Böröcz (2001) a jeho tým, kteří nepoužívají spojení „rozšíření“ EU, ale významně mluví o „expanzi““ EU a tvrdí, že jsme svědky nové formy kolonialismu. Musíme však připustit, že EU používá svou sílu a prestiž neúměrně a z velké části si to neuvědomuje; v Evropě je tento jev ve vztahu velkého a malého státu inherentní. Proto jsou reprodukovány nejasnosti, jež ve střední Evropě přetrvávají od začátku modernity.

Vztah velkého a malého státu je většinou ignorován při vyjednávání i v akademické literatuře. Tento vztah má rovněž vliv na malé západní státy, ačkoliv ty do vztahu vstupují s jinou historickou zkušeností než státy postkomunistické. Malé státy mají inherentní potíže s hledáním uznání, statusu a úcty, které pocitují jako patřičné pro vědomí kulturní jistoty a především zabezpečení vlastní kulturní reprodukce. Když se problém malých států objeví v agendě, jsou velké evropské státy nedůtklivé a podrážděné, jako například Francie na summitu v Nice. Chybou všech velkých států - Francie, Spojeného království, Německa, Itálie - je tato netrpělivost, neochota přijmout, že zatímco ony samy nemusí mít problémy s rovností úcty, malé státy je mají.

Všechny státy stř̌ední Evropy jsou malé, včetně Polska, územně středně velkého, avšak psychologicky malého v důsledku jeho fragmentovaných dějin (trojí dělení, posuny hranic, zničení Varšavy, vliv komunismu). Pro Středoevropany znamená členství v EU mnohem více než jen připojení ke společnému trhu - představuje formu uznání, uznání jako rovnocenného člena symbolické Evropy. Velké státy mohou toto tvrzení ignorovat, ale tím nebude odstraněno.

Když byla po roce 1945 vytvořena EU, měla řadu jasně daných cílů. Jak jsem se již zmínil, jedním z nich byl trvalý smír mezi Francií a Německem. To se podařilo dokonale. Dalším cílem bylo vytvoření takové míry vzájemné závislosti, aby konflikty musely být řešeny vyjednáváním. Třetím cílem pak bylo zachování evropského sociálního státu a transformace zbytků rurální populace v občany, a právě to je jeden z nejvýznamnějších evropských historických projektů. Existoval a existuje také čtvrtý cíl: vytvoření prostoru, ve kterém je možné zabývat se otázkou vnější i vnitřní bezpečnosti malých států, tedy prostoru, v němž by se malé státy cítily bezpečně.

Demokracie a teorie demokracie ovšem vyžadují, aby ti, kteří jsou ovlivněni mocí, měli svůj hlas, aby ti, kteří mají moc, praktikovali sebeomezení a aby ve vzájemném vztahu existovala úcta a shoda, že závazky bez reprezentace jsou receptem na problémy. Ve skutečnosti však lze položit řadu oprávněných otázek: Exportoval Západ demokratický deficit EU do střední Evropy tím, že při vyjednávání o rozšíření používal určitých metod, přispěla EU neúmyslně k zachování liminálního stavu postkomunismu, a jak se to vše změní poté, co se kandidátské země stanou plnohodnotnými členy? 


\section{Středoevropská synteze}

Poslední otázka se týká povahy hlasu, který Středoevropané mohou využít jako členové EU. Přestože kulturní velmoci Západu uznají, že menší západoevropské země mohou přispět k evropskému diskurzu, mají tendenci myslet si, že oligopol evropských diskurzů vlastní samy. Nevšímají si toho, že existují ještě slabé hlasy vycházející ze střední Evropy, které jsou paradoxně bližší celoevropské syntéze než cokoliv pocházející ze Západu.

Tento proces je ještě v raném stadiu, má dvě dimenze. V první řadě pozorujeme intelektuální obnovu po období marxisticko-antimarxistického paradigmatu. V sociálních a humanitních vědách došlo $\mathrm{k}$ jakési fúzi importovaných západních a zděděných rámců. Kvalita domácích analýz vzrostla natolik, že vyžaduje pozornost, není už tudíž možné zabývat se postkomunistickými zeměmi bez znalosti místních jazyků.

Dále můžeme pozorovat cosi jako syntézu vycházející ze střední Evropy, cosi, co nenacházíme na Západě. Střední Evropa je na okraji Evropy, a proto si uvědomuje, že musí sledovat intelektuální dění v celé Evropě. Navíc ve střední Evropě přetrvává dědictví baroka a protireformačního myšlení, jehož klíčovou složkou je vytvoření integrované vize světa. Středoevropské myšlení tedy rozhodí svou sít' tak daleko, jak je to jen možné, střední Evropa se bude snažit převzít všechny možné př́stupy, aby zajistila, že jsou prozkoumány všechny struktury a navázána všechna spojení. Středoevropané ve snaze, aby byli bráni vážně, nutně absorbují anglosaskou, německou a francouzskou literaturu a někdy také literaturu ruskou a/ nebo italskou. To je na Západě spíše výjimečné. ${ }^{5}$

I když nadvláda anglosaských metodologií není absolutní, jen zřídkakdy čerpají britští a američtí spisovatelé zároveň z francouzského i německého myšlení. Vždy existuje několik jmen, jako Foucault nebo Habermas, která jsou přijata, ale jimi poznání končí. Rusisté znají Bachtina, ale jen málokdy srovnávají jeho díla např́iklad s Foucaultovými. Naznačuji tím, že taková syntéza není ve střední Evropě neobvyklá. Ve srovnání se Spojenými státy nebo Spojeným královstvím má silnější vliv obzvláště německé myšlení. Možná je odvážné argumentovat tímto způsobem, ale soudíme, že pokud bude př́íší vize budoucnosti Evropy pocházet ze střední Evropy, pak tento druh syntézy sehraje svou roli.

Závěrem lze konstatovat, že obraz je komplexní. EU v současnosti zavádí nové institucionální struktury, které jí umožní fungovat s novými členskými státy, ale zavádí je bez výrazného vkladu nových členů. Střední Evropa vstoupí do EU s takřka nezměněným kulturním kapitálem, a tak střet těchto diskurzů pravděpodobně způsobí neshody mezi ní a dosavadními členy EU. Proto budou středoevropské diskurzy marginalizovány, ačkoliv by díky svému zhuštění teoreticky mohly v Evropě rychle zdomácnět. Zároveň pokud nedojde k výrazným inovacím v institucionálních rámcích, vztazích a př́stupech, budou z EU vynechány státy jihovýchodní Evropy. Jihovýchodní Evropa, která zůstane mimo evropský mainstream, není ničím novým, ale nepřispěje ke stabilitě.

Přeložila Monika Metyková 


\section{Poznámky}

1 K liminalitě, kterou můžeme zhruba definovat jako stav „uprostřed“ (in-betweenness), viz van Gennep (1960) a Turner (1995).

2 Některé tyto otázky jsou diskutovány v Schöpflinovi (2002).

3 Andrzej Lepper je předsedou polské pravicové populistické politické strany Samoobrona (Sebeobrana). István Csurka je předsedou mad’arské politické strany MIÉP (Strana mad’arské pravdy a života). Jedná se o pravicovou stranu, která se charakterizuje jako radikální národní strana (pozn. překl.).

$4 \quad$ Glenny (1999) to tvrdí ve vztahu k jihovýchodní Evropě; v případě střední Evropy nacházíme podobnosti ve struktuře.

$5 \quad$ Př́klady podobných děl jsou v tomto článku uváděny ze syntéz, které byly vydány v Mad’arsku, ale analogické prrípady nacházíme i jinde ve střední Evropě. Velmi nahodilý výběr takových prací by zahrnoval: Némedi (2000), Hankiss (1997), Bókay (2001), Boglár (2001) a Lánczi (2000).

\section{Bibliografie}

Bauman, Z. 1994. „After the Patronage State: A Model in Search of Class Interests“ In Ch. Bryant, E. Mokrzycki (eds.) The New Great Transformation. London: Routledge, s. 14-35.

Bauman, Z. 1987. Legislators and Interpreters. Cambridge: Polity.

Boglár, L. 2001. A kultúra arcai: mozaikok a kulturális antropológia köréböl. Budapest: Napvilág. Bókay, A. 2001. Irodalomtudomány a modern és a posztmodern korban. Budapest: Osiris.

Böröcz, J. (ed.) 2001. Empire's New Clothes: Unveiling EU Enlargement. [HTML dokument] dostupný z: http//:www.ce-review.org/ebookstore/rutgers1.html

Douglas, M. 1992. Risk and Blame: Essays in Cultural Theory. London: Routledge. van Gennep, A. 1960. The Rites of Passage. Chicago: University of Chicago Press.

Glenny, M. 1999. The Balkans 1804-1999: Nationalism, War and the Great Powers. London: Granta.

Hankiss, E. 1997. Az emberi kaland: egycivilizació-elmélet vázlata. Budapest: Helikon.

Lánczi, A. 2000. Demokrácia és politikatudomány. Budapest: Aula.

Nemesi, D. 2000. Társadalomelmélet-elmélettörténet. Budapest: Új Mandátum.

Schöpflin, G. (ed.) 2000. The Westward Enlargement of Central Europe. London: British Council and SSEES.

Turner, V. 1995. The Ritual Process: Structure and Anti-Structure. New York: Aldine de Gruyter.

\section{Autor}

George Schöpflin je Jean Monnet profesorem politologie a ředitelem Centra pro studium nacionalismu na School of Slavonic and East European Studies, University of London. Je autorem řady publikací s tematikou národa, nacionalismu a etnicity, s důrazem na postkomunistické země. 